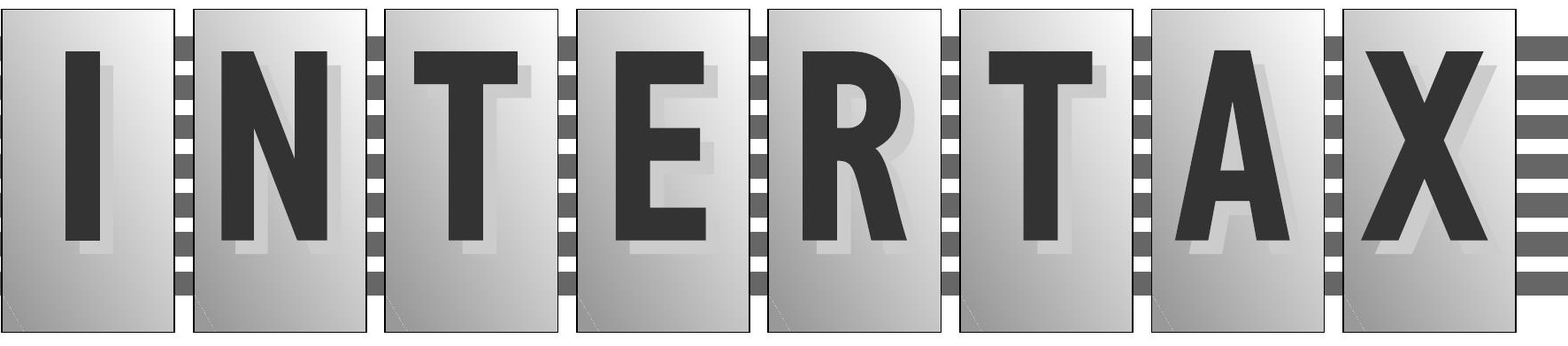

Q. Wolters Kluwer Law \& Business 
Editorial Board:

Fred C. de Hosson, General Editor, Baker \& McKenzie, Amsterdam Prof. Alexander Rust, Vienna University of Economics and Business Dr Philip Baker OBE, QC, Barrister, Field Court Tax Chambers, Senior

Visiting Fellow, Institute of Advanced Legal Studies, London University Prof. Dr Ana Paula Dourado, University of Lisbon, Portugal

Prof. Yariv Brauner, University of Florida, USA

Prof. Edoardo Traversa, Universite Catholique de Louvain, Belgium

Editorial address:

Fred C. de Hosson

Claude Debussylaan 54

1082 MD Amsterdam

The Netherlands

Tel: (int.) +31 205517555

Fax: (int.) +3120551 7121

Email: Fred.deHosson@bakermckenzie.com

Book reviews:

Pasquale Pistone

via G. Melisurgo

1580133 Naples

Italy

Email: ppistone@mclink.it

Published by:

Kluwer Law International

PO Box 316

2400 AH Alphen aan den Rijn

The Netherlands

Website: www.wklawbusiness.com

Sold and distributed in North, Central and South America by: Aspen Publishers, Inc.

7201 McKinney Circle

Frederick, MD 21704

United States of America

Email: customer.service@aspenpublishers.com

Only for Intertax

Sold and distributed in Germany, Austria and Switzerland by:

Wolters Kluwer Deutschland GmbH

PO Box 2352

56513 Neuwied

Germany

Tel: (int.) +4926318010

Sold and distributed in Belgium and Luxembourg by:

Établissement Émile Bruylant

Rue de la Régence 67

Brussels 1000

Belgium

Tel: (int.) + 3225129845
Sold and distributed in all other countries by:

Turpin Distribution Services Ltd.

Stratton Business Park

Pegasus Drive, Biggleswade

Bedfordshire SG18 8TQ

United Kingdom

Email: kluwerlaw@turpin-distribution.com

Intertax is published in 12 monthly issues

Print subscription prices 2015: EUR 1194/USD 1593/GBP 878

(12 issues, incl. binder)

Online subscription prices 2015: EUR 1106/USD 1474/GBP 813

Intertax is indexed/abstracted in IBZ-CD-ROM; IBZ-Online

For electronic and print prices, or prices for single issues,

please contact our sales department for further information.

Tel: (int.) +31 (0)70 3081562

Email: sales@kluwerlaw.com

For Marketing Opportunities

Please contact marketing@kluwerlaw.com

Printed on acid-free paper.

ISSN: 0165-2826

(c) 2015 Kluwer law International BV, The Netherlands

All rights reserved. No part of this journal may be reproduced, stored in a retrieval system or transmitted in any form or by any means, electronic, mechanical, photocopying, recording or otherwise, without written permission from the publisher, with the exception of any material supplied specifically for the purpose of being entered and executed on a computer system, for exclusive use by the purchaser of the work.

Permission to use this content must be obtained from the copyright owner. Please apply to: Permissions Department, Wolters Kluwer Legal, 76 Ninth Avenue, 7th Floor, New York, NY 11011-5201, USA. Email: permissions@kluwerlaw.com.

Printed and Bound by CPI Group (UK) Ltd, Croydon, CRO 4YY.

Articles can be submitted for peer review. In this procedure, articles are evaluated on their academic merit by two (anonymous) highly esteemed tax law experts from the academic world. Only articles of outstanding academic quality will be published in the peer-reviewed section. 


\title{
The OECD-BEPS Measures to Deal with Aggressive Tax Planning in South America and Sub-Saharan Africa: The Challenges Ahead
}

\author{
Irma Johanna Mosquera Valderrama*
}

\begin{abstract}
The aim of this article is to assess the feasibility to introduce the Organisation for Economic Co-operation and Development (OECD)-BEPS measures to deal with aggressive tax planning in South America and Sub-Saharan Africa. The BEPS and its Action Plan have been developed by the OECD following the G20 mandate and it provides new international tax standards to be applicable to all countries including OECD and non$O E C D$ countries. This article will provide a comparative analysis of the South America and the Sub-Sabaran African region taking into account the country's economic development, tax administration capacity and resources, and the use (or not) of domestic laws and tax treaty rules to tackle aggressive tax planning. The South American and Sub-Saharan African regions bave been chosen since they consist mostly of developing (non$O E C D$ ) countries. The comparative analysis of the exchange of best practices and challenges in these two regions will be useful for the OECD-BEPS Project and for the BEPS Multilateral Instrument that will be open for adoption by developing and developed countries. This article is structured as follows: Section 2 contains a short introduction to the BEPS Actions dealing with aggressive tax planning and the discussions at OECD and UN level. Section 3 will provide the assessment of feasibility of the BEPS in South America and Sub-Sabaran Africa. Finally, in section 4, conclusions and recommendations will be presented.
\end{abstract}

\section{INTRODUCTION}

The main aim of this article is to assess the feasibility to introduce the Organisation for Economic Co-operation and Development (OECD)-BEPS measures to deal with aggressive tax planning in South America and Sub-Saharan African regions. The South American and Sub-Saharan African regions have been chosen since they consist mostly of developing (non-OECD) countries. This article will provide a comparative analysis of the South America and Sub-Saharan African region taking into account the country's economic development, tax administration capacity and resources, and the use (or not) of domestic laws and tax treaty rules to tackle aggressive tax planning. The comparative analysis of the exchange of best practices and challenges in these two regions will be useful for the OECD-BEPS Project and for the BEPS Multilateral
Instrument that will be open for adoption by developing and developed countries.

In 2013, the OECD following the political G20's mandate ${ }^{1}$ launched the BEPS Report and its Action Plan. ${ }^{2}$ The OECD in the BEPS Action Plan calls for 'fundamental changes to the current mechanisms and the adoption of new consensus-based approaches, including anti-abuse provisions, designed to prevent and counter base erosion and profit shifting. ${ }^{3}$ The BEPS Action Plan introduces two actions for aggressive tax planning being Action 6 dealing with tax treaty abuse and Action 12 requiring taxpayers to disclose their aggressive tax planning arrangements.

Aggressive tax planning 'exploits the differences in tax systems by taking advantage of the technicalities of a tax system or of mismatches between two or more tax systems for the purpose of reducing tax liability'. ${ }^{4}$

\section{Notes}

Dr Irma Johanna Mosquera Valderrama Lecturer at The Hague University of Applied Sciences, Postdoctoral Research Fellow at the International Bureau of Fiscal Documentation and Tax Adviser at Hamelink \& Van den Tooren, the Netherlands. The author can be contacted at irma.mosquera@gmail.com. The author gratefully acknowledges the comments of Professor Frederik Zimmer to an early draft version of this article. The views expressed herein are, however, solely those of the author.

The BEPS and the Action Plan have been endorsed in the G20 meetings at Mexico (June 2012) and St Petersburg (September 2013) respectively. G20 Leaders Declaration in St. Petersburg of 6 Sep. 2013. See in particular, para. 50 of the Declaration, where it has been stated that: 'In a context of severe fiscal consolidation and social hardship, in many countries ensuring that all taxpayers pay their fair share of taxes is more than ever a priority. Tax avoidance, harmful practices and aggressive tax planning have to be tackled...'. See https://www.g20.org/sites/default/files/g20_resources/library/Saint_Petersburg_Declaration_ENG_0.pdf (Accessed February 2015).

OECD (2013), Addressing Base Erosion and Profit Shifting, OECD Publishing. Available at http://dx.doi.org/ 10.1787/9789264192744-en and OECD (2013), Action Plan on Base Erosion and Profit Shifting, OECD Publishing, Available at http://dx.doi.org/10.1787/9789264202719-en (Accessed February 2015).

Ibid., at 13 .

European Commission Recommendation of 6 Dec. 2012 on Aggressive Tax Planning C (2012)8806 Final at 2. 
In 2014, the International Monetary Fund (IMF) published a policy paper addressing the Spillovers - the impact that one country's international tax practice has on other countries - in International Corporate Taxation. The IMF stated that for developing countries, the key issues are preventing tax treaty shopping, indirect transfer of interest in assets, interest deductibility and the introduction of clear and simplified transfer pricing rules. ${ }^{5}$

The OECD published in 2014 a report addressing the impact of BEPS in Low Income Countries (the Report). In the first part of the Report, the OECD addressed the experiences of developing countries on the main sources of base erosion profit shifting in developing countries and the way that these experiences may relate to the BEPS Action Plan. ${ }^{6}$ In the second part of the Report, the OECD presented the potential actions to assist developing countries to meet the challenges of the most relevant actions of the BEPS.

The Financing for Development Office of the United Nations (UN) has also addressed the BEPS in two workshops dealing with Tax Base Protection for Developing Countries. ${ }^{7}$ In these workshops, selected BEPS issues $^{8}$ have been analysed by scholars, government officials of developing countries under the auspices of the $\mathrm{UN}$ and with the cooperation of the OECD.

The IMF Paper, the OECD Report, and the UN workshops including the background papers have addressed the challenges faced by developing countries to prevent tax erosion. Among these challenges are the implementation of BEPS measures and the use of tax incentives in developing countries. Other issues that are also addressed for developing countries are the allocation of tax treaty rights in accordance to residence and source, the tax treaty costs/benefits analysis to be made for the negotiation of tax treaties, the introduction of transfer pricing rules and the limited administrative capacity of tax administrations.

This article is structured as follows: Section 2 contains a short introduction to the BEPS Actions dealing with aggressive tax planning and the discussions at OECD and UN level. Section 3 will provide the assessment of feasibility of the BEPS in South America and Sub-Saharan Africa. Finally, in section 4, conclusions and recommendations will be presented.

\section{BEPS ACtions tO TACKLE AGgRESSIVE tAX PLANNING FROM AN OECD AND UN PER- SPECTIVE}

\section{I Action 6: Dealing with Tax Treaty Abuse}

Action $6^{9}$ is divided in three sections. Section $\mathrm{A}$ aims to prevent the granting of treaty benefits in inappropriate circumstances; ${ }^{10}$ section B aims to clarify that tax treaties are not intended to generate double taxation; ${ }^{11}$ and section $\mathrm{C}$ aims to identify tax policy considerations for countries to take into account before deciding whether or not to conclude a tax treaty. ${ }^{12}$ This Action 6 has been further developed in a consultation draft (the Draft) made by the Working Party 1 of the OECD available for public discussion in March 2014. A public consultation of the Draft was held at the headquarters of the OECD in April 2014.

Following the invitation of the OECD, comments were received from business organizations, NGOs, companies, tax advisers, among others. These comments were mostly critical regarding the measures proposed in the draft. ${ }^{13}$ In addition, the objectives of Action 6 and the contents of the draft have been also discussed and critically reviewed by

\section{Notes}

IMF Policy Paper Spillovers in International Corporate Taxation 9 May 2014, International Monetary Fund, Washington, D.C., 24.

Part 1. Report to G20 Development Working Group on the Impact of BEPS in Low Income Countries. July 2014. Report available at http://www.oecd.org/ctp/tax-global/part -1-of-report-to-g20-dwg-on-the-impact-of-beps-in-low-income-countries.pdf.

The first workshop on Tax Base Protection for Developing Countries took place in New York, the United States on 4 Jun. 2014. The second workshop on took place in Paris, France on the 23 Sep. 2014.

8 The first workshop addressed preventing tax treaty abuse, taxation of services including taxation of fees for technical services, protecting the tax base in the digital economy, tax incentives and tax base protection issues. In the second workshop, the following topics were addressed permanent establishment, hybrid mismatches, limiting interest deductions, taxation of capital gains, treaty abuse and transparency and disclosure. Agenda, presentations and background materials for the two workshops are available at the website of the UN Financing for Development available at http://www.un.org/esa/ffd/ (Accessed February 2015).

9 OECD (2014), Action 6: Preventing the Granting of Treaty Benefits in Inappropriate Circumstances, OECD/G20 Base Erosion and Profit Shifting Project, OECD Publishing. DOI: 10.1787/9789264219120-en, 3-21. (Accessed February 2015).

10 In respect of treaty benefits in s. A, the Draft proposes to introduce provisions in the tax treaties to tackle tax treaty abuse mainly by addressing tax treaty shopping. The Draft recommends including in the title and preamble that the objectives of the treaties are to tackle tax avoidance and in particular to avoid creating opportunities for treaty shopping. Furthermore, it recommended the use of a limitation on benefits provision and the introduction of a more general anti-abuse rule for situations that would not be covered by the limitation on benefits provision such as certain conduit arrangements. Ibid., 3-21.

11 In respect of s. B, the Draft proposes changes to the title of the OECD Model Convention to include the prevention of tax evasion and tax avoidance. The Draft also proposes changes to the preamble to include that tax treaties aim to prevent double taxation and that treaties do not aim to create situations of double non-taxation or reduced taxation. Ibid., 28

12 Finally, s. C introduces the tax policy considerations that may relevant for countries to take into account before concluding tax treaties. Among these considerations are to prevent double taxation, to prevent excessive taxation resulting from high withholding taxes at source, to prevent discriminatory treatment of foreign investment (Art. 24 OECD Model), to tackle tax evasion and tax avoidance including the introduction of exchange of information, and to provide assistance in the collection of taxes. Ibid., $30-31$.

13 See comments to the draft at the OECD Website at http://www.oecd.org/tax/discussion-draft-action-6-prevent-treaty-abuse.htm (Accessed February 2015). 
academic scholars. ${ }^{14}$ The main conclusion of these reviews is that the draft needs to be revisited mainly in respect of the application of section A proposed measures such as limitation on benefits and general anti-abuse clause. The OECD has revisited this draft in September 2014. ${ }^{15}$ More recently, a new draft regarding the follow up work on BEPS Action 6 was made available for public discussion on 21 November 2014. ${ }^{16}$ A public consultation of the Draft was held at the headquarters of the OECD in January 2015.

In the public consultation in January 2015, the impact of Action 6 in developing countries was shortly addressed. The main comment addressed the feasibility of the developing countries to implement the treaty abuse measures of Action 6 since these measures will coexist with the domestic anti-avoidance rules of the countries. In this case, it was recommended by one of the speakers to try to find a default provision to limit the proliferation of anti-abuse clauses. The reason behind is that the expectation for developing countries to apply a range of different anti-abuse measures would unnecessarily strain their administrative capacity. For this purpose, it was recommended to the OECD-Committee of Fiscal Affairs to make an inventory of developing countries preferred type of anti-abuse measure and then to find out whether these countries will prefer a single type anti-abuse measure and this to be presented as the default provision. ${ }^{17}$ Another speaker reflected on this proposal stating that the use of a default provision may result in simplicity rather than complexity and therefore developing countries will benefit from the introduction of a default provision. ${ }^{18}$

\subsection{Action I2: Disclosure Aggressive Tax Planning}

Action 12 proposes the design of mandatory disclosure rules for aggressive or abusive transactions, arrangements, or structures. According to the OECD, a discussion draft will be published in March 2015. ${ }^{19}$ At the time of writing (February 2015), the content of the mandatory disclosure rules that will be presented in Action 12 is not yet known. ${ }^{20}$
The first element to keep in mind in respect of Action 12 is that the disclosure of tax structures may result in separate and different disclosure rules to be imposed by countries that may constitute a burden to the taxpayers and to the tax administration especially in developing countries that are dealing with the implementation of transfer pricing rules. In these countries, transfer pricing rules (if existent) are new and therefore, the tax administrations are still dealing with issues regarding the transfer pricing methods, documentation, etc. The OECD when developing this Action 12 should take into account that the disclosure rules should not constitute an excessive burden for the taxpayer to comply and for the tax administration to enforce.

Furthermore, the OECD should take into account how the disclosure rules of Action 12 will be combined with the transfer pricing documentation of Action 13. Action 13 deals with transfer pricing documentation that provides for exchange of information of documentation from the local affiliated under examination but also from the multinational group of companies such as master file, local file and country-by-country reporting.

The OECD should also address the measures to protect the confidentiality of the information that will be disclosed by the taxpayer in accordance to Action 12 . Until now, the issue of confidentiality has not been an issue of concern in the OECD-BEPS since the BEPS documents for these Actions have referred to the OECD guide on confidentiality and to the international instruments to exchange information such as tax treaties, Tax Information Exchange Agreements (TIEAs), the Multilateral Convention on Administrative Assistance in Tax Matters among others.

It is this author's opinion that since Action 12 aims to design and put in place enhanced models of information sharing for international tax schemes between tax administrations, this will result in exchange of information of personal and financial data, and/or business strategies among others. The exchange of this information should not constitute a risk in case that the country does not provide sufficient safeguards to protect the confidentiality.

\section{Notes}

14 See M. Lang, BEPS Action 6. Introducing an Anti-abuse Rule in Tax Treaties, Tax Notes Int'l 655-664 (19 May 2014); Y. Brauner, BEPS: An Interim Evaluation, World Tax Journal 26-28 (February 2014), IBFD, Amsterdam.

15 The new draft states that the application of the Limitation on Benefits clause is still being revisited. Accordingly, 'the model provisions and related Commentary included in section A of this report should therefore be considered as drafts that are subject to improvement before their final versions are released in September 2015.' Supra n. 9 at 10.

16 Public Discussion Draft: Follow up work on BEPS Action 6: Preventing Treaty Abuse. Commentaries may be given to this Draft until 9 Jan. 2015. Draft available at: http:// www.oecd.org/ctp/treaties/discussion-draft-action-6-follow-up-prevent-treaty-abuse.pdf (Accessed February 2015).

17 Public Comments to Draft Action 6 made by Francis Weyzig on behalf of the BEPS Monitoring Group. Available at http://www.oecd.org/ctp/treaties/public-comments-action -6-follow-up-prevent-treaty-abuse.htm (Accessed February 2015).

18 See webcast public consultation at http://www.oecd.org/ctp/treaties/public-consultation-action-6-follow-up-prevent-treaty-abuse.htm (Accessed February 2015)

19 See deadlines for discussion drafts http://www.oecd.org/ctp/discussiondrafts.htm (Accessed February 2015).

20 According to the OECD Calendar for stakeholders input, the consultation draft will be available in Late March 2015. http://www.oecd.org/ctp/calendar-planned-stakeholders -input.pdf (Accessed February 2015). 
In the past, the exchange of international tax schemes was made by means of the OECD's directory to exchange aggressive tax planning structures and arrangements. This Directory is still used and it is available to the tax administrations of the OECD that have actively contributed to the directory. ${ }^{21}$ In this framework, it is submitted that Action 12 should aim to provide more than only exchange of international tax schemes and best practices. As rightly stated by Brauner, Action 12 may raise questions regarding how this action can contribute to the evolution of the international tax regime and on whether this action is, more focused on exchange of best practices than on tax base erosion actions. ${ }^{22}$

Finally, the OECD should keep in mind that Action 12 should also aim at developing a closer and enhanced relationship where the governments (tax administration) are able to have access to the information regarding the activities of the taxpayer and the taxpayers voluntary provide disclosure on the way that the economic activities or businesses are being structured in a country.

\subsection{OECD Report: Impact of BEPS in Low Income Countries}

The first part of the OECD Report published in July 2014 evaluates the impact of the Action Plan in Low Income Countries and it adds other issues that should be considered for these countries that are not included in such action plan (e.g., use of tax incentives by developing countries). The Report follows consultations with developing countries and international organizations mainly the IMF.

The first part of the Report elaborates on Action 6; however, no further reference in the Report is made to Action 12. In respect of Action 6, the Report states that the concern of developing countries 'is focused on the use of techniques (sometimes called "treaty shopping") to obtain treaty benefits (typically the reduction of withholding taxes) in situations in which such benefits were not intended'. This results in developing countries losing revenue. ${ }^{23}$ In addition, the Report states that the unintended use of treaties to avoid withholding taxes should be tackled by means of domestic rules and tax treaty provisions.

In respect of tax incentives, the first part of the report addresses the work of the IMF and the World Bank in respect of tax incentives. Tax incentives have a direct impact on the tax base of developing countries and give rise to no taxation or taxation at a lower rate, the report stated that 'it is important to address this issue alongside other developing countries BEPS issues'. ${ }^{24}$

Another issue that it was addressed in the first part of the report that affects developing countries is the balance between source and resident taxation in the tax treaties following the UN Model or the OECD Model. The OECD stated in the report ${ }^{25}$ that 'this is an issue of allocating tax rights between treaty partners. It is not a tax planning/ avoidance issue and does not give rise to BEPS'. The OECD also stated that in principle, this issue is outside the scope of this report, but since this an issue of significance for many developing countries; the OECDBEPS project 'provides an opportunity to lay the ground for this legitimate debate'. Furthermore, the BEPS consultations with developing countries have also highlighted the 'need to critically assess the costs and benefits of entering into tax treaties, and balance the policy objectives of revenue collection on the one hand and creating the right environment for Foreign Direct Investment (FDI) on the other'. ${ }^{26}$

In the second part of the Report, the OECD presents the potential actions to assist developing countries to meet the challenges of the most relevant actions of the BEPS. The Report states that in order to address treaty shopping it is important to strengthen the capacity development on treaty negotiation and to identify the tax policy considerations for countries to conclude a tax treaty including a cost/benefit analysis. ${ }^{27}$

\section{Notes}

21 According to the OECD:

the directory contains information on scheme types, how they were detected, and what governments are doing about them. It does not contain any taxpayer-specific information (i.e., they do not disclose the identity of the taxpayers involved) and thus protects taxpayer privacy. Schemes set out fact patterns and the legal provisions being exploited. The inclusion of a scheme shows that one or more countries thought it useful to share information on a scheme with other interested countries, but it does not indicate any legal or other judgment about the scheme on the part of the OECD or its membership.

http://www.oecd.org/ctp/aggressive/oecdaggressivetaxplanningdirectory.htm (Accessed February 2015).

22 Y. Brauner. BEPS supra n. 14 at 36

23 The Report provides two examples of countries (i.e., Mongolia, the Netherlands) that are currently reviewing their tax treaties and in some cases reviewing the measures available in their tax treaties to tackle treaty abuse. Part 1 of a Report to G20 Development Working Group on the Impact of BEPS in Low Income Countries supra n. 6 at 18.

Ibid., at 8 .

Ibid., at 9 .

Ibid., at 9 .

Part 2 Report to G20 Development Working Group on the Impact of BEPS in Low Income Countries. August 2014. Report available at http://www.oecd.org/ctp/tax-global /part-2-of-report-to-g20-dwg-on-the-impact-of-beps-in-low-income-countries.pdf at 15. 


\subsection{UN Protecting the Tax Base of Developing Countries}

The UN has addressed the BEPS issues from the perspective of developing countries. For this purpose, a questionnaire on BEPS issues was made available including also background papers drafted by legal scholars regarding specific topics. The topics addressed by the questionnaire and the background papers have been discussed in two workshops. ${ }^{28}$ For the topic of this article, the relevant papers are the papers on Protecting the Tax Base of Developing Countries, ${ }^{29}$ Transparency and Disclosure $^{30}$ and Preventing Tax Treaty Abuse. ${ }^{31}$

The responses to the questionnaire by developing countries $^{32}$ were limited since only Lesotho, ${ }^{33}$ Ghana, ${ }^{34}$ Tonga ${ }^{35}$ and $Z^{2}{ }^{3} b i a^{36}$ provided short answers to the questionnaire. ${ }^{37}$ The main issues that these countries addressed were the following

In respect of the International Instruments, the main concerns were the lack of double tax treaties (Tonga); lack of exchange of information instruments (Tonga, Lesotho); the need to ensure that there is more taxation at source of capital gains (Lesotho); and to introduce measures to prevent treaty shopping (Zambia).

In respect of availability of domestic rules: The concerns were the lack of specific rules relating to permanent establishment including branches (Tonga); lack of regulation of the informal (cash) economy (Tonga); introduction of rules dealing with transfer pricing documentation (Zambia); higher tax rates that result in the use of other countries in tax planning in order to reduce the tax liability in the country (Lesotho); and the need to introduce limitations to the deductions for management fees, interest and royalties (Lesotho).

In respect of implementation of domestic rules: Introduction of guidelines to apply the arm's length principle in transfer pricing (Tonga); implementation of tax avoidance rules (Zambia); lack of database to conduct the comparability analysis in respect of transfer pricing (Ghana); to prevent the tailoring of activities by multinationals so that such activities will not be deemed to constitute a permanent establishment in the developing country (Zambia)

In respect of administrative capacity: Limited skills to audit some of the highly specialized sectors (Lesotho).

Other tax issues that may be relevant for developing countries have been addressed by Lesotho and Zambia. These issues are for Lesotho: the lack of voluntary disclosure by multinationals; the lack of availability of responsible personal to discuss tax issues within the multinational; 38 in case of a subsidiary the tax reporting of the multinational activities is made in accordance to the laws of the parent company and not in accordance to the laws of the subsidiary; in some cases the accounting records are kept abroad and the information provided by the multinational and/or subsidiary is usually late. For Zambia: tax base erosion that results from the creation of new companies just for the purposes of using tax incentives in specific sectors of investment.

The measures that have been introduced by these countries are for instance in Tonga: introduction of a new Income Tax Law; Zambia: capacity building and creation of a transfer pricing unit; re-negotiation of old tax treaties to prevent tax treaty abuse; strengthening the domestic anti-abuse legislation; reducing the tax holidays; Lesotho: tax auditing; and Ghana: introduction of transfer pricing and domestic anti-avoidance rules.

What this all means is then that the BEPS proposed Actions 6 and 12 as presented by the OECD may differ from the needs of developing countries. As expressed by the developing countries, the main issues are the lack of tax administrative and technical capacity, tax base erosion

\section{Notes}

28 These papers are available at the website of the United Nations as Background Material to the Second Workshop on Tax Base Protection for Developing Countries Information available at: http://www.un.org/esa/ffd/events/cd-2014-tax-second-workshop.html (Accessed February 2015).

29 H. Ault \& B. Arnold, Protecting the Tax Base of Developing Countries: An Overview. Draft paper No. 1 May 2013. This paper is available in the background material of the First Workshop at http://www.un.org/esa/ffd/uncategorized/tax-first-workshop.html (Accessed February 2015).

30 D. Ring, Transparency and Disclosure. September 2014. Available at http://www.un.org/esa/ffd/wp-content/uploads/2014/09/20140923_Paper_PreventingTaxTreatyAbuse. pdf (Accessed February 2015).

31 G.S. Cooper, Preventing Tax Treaty Abuse. September 2014. Available at http://www.un.org/esa/ffd/wp-content/uploads/2014/09/20140923_Paper_PreventingTaxTreaty Abuse.pdf (Accessed February 2015).

32 Other countries that provided answers to the questionnaire are Brazil, Chile, China, India, Malaysia, Mexico, South Africa, Singapore and Thailand. See summary responses to BEPS questionnaire available at http://www.un.org/esa/ffd/wp-content/uploads/2014/10/10STM_CRP12_BEPS1.pdf (Accessed February 2015).

33 Answers by Lesotho to BEPS questionnaire available at http://www.un.org/esa/ffd/wp-content/uploads/2014/12/ta-BEPS-CommentsLesotho.pdf (Accessed February 2015).

34 Answers by Ghana to BEPS questionnaire available at http://www.un.org/esa/ffd/wp-content/uploads/2014/09/20140923_CommentsGhana_BEPS.pdf (Accessed February 2015).

35 Answers by Tonga to BEPS questionnaire available at http://www.un.org/esa/ffd/wp-content/uploads/2014/09/20140923_CommentsTonga_BEPS.pdf (Accessed February 2015).

36 Answers by Zambia to BEPS questionnaire available at http://www.un.org/esa/ffd/wp-content/uploads/2014/09/20140923_CommentsZambia_BEPS.pdf (Accessed February 2015).

37 In addition, two NGOs' provided their answers being Christian Aid/Action Aid and Oxfam South Africa.

38 In the questionnaire of Lesotho, it was stated that there is a branch manager that have limited knowledge and the tax issues including tax planning are being dealt at the level of the Head Office/MNE rather than at the level of the branch. 
through tax incentives, and problems in the drafting and implementation of domestic rules. In addition, developing countries are still in the process of developing an international treaty network that also includes negotiation of bilateral tax treaties and exchange of information agreements (TIEAs).

These countries may benefit more from exchange of best practices and of technical assistance for drafting and implementing tax rules including careful selection of tax incentives. It is the author's opinion that the UN and the OECD can benefit from a close engagement in the BEPS that also respond to the needs of developing countries. For this purposes, the issues that have addressed by Ghana, Tonga, Lesotho and Zambia should be also taken into account not only by the UN but also by the OECD.

Furthermore, the UN and the OECD should enhance the exchange of best practices that developing countries have taken to dealt with tax avoidance, tax auditing, transfer pricing, exchange of information, etc. Some of these issues have been dealt with in the framework of the Project Sustainable Tax Governance in Developing Countries Through Global Tax Transparency (DeSTaT) where for instance the countries policy on aggressive tax planning was researched. The following issues were addressed domestic anti-abuse rules to tackle aggressive tax planning; policy issues of the selected countries regarding international tax arbitrage; the regime (if any) regarding holding companies; the existence (or not) of enhanced relationships between taxpayers and multinationals, and finally issues such as conduit structures, foreign direct investment and administrative cooperation. ${ }^{39}$

The following section will deal with the main features of countries in South America and Sub-Saharan Africa that may influence the BEPS and its Actions 6 and 12 to tackle aggressive tax planning. These features address the country's economic development, tax administration capacity and resources, and the use or not of domestic laws and tax treaty rules to tackle aggressive tax planning. These issues may be useful for the OECD, the UN and for the International Conference that will be developing the BEPS Multilateral Instrument.

\section{Feasibility of action 6 and I 2 to TACKLE AGGRESSIVE TAX PLANNING FOR COUNTRIES IN THE AFRICAN AND LATIN AMERICAN REGIONS}

\section{I Country's Economic Development}

Until the nineties countries such as Brazil, Argentina, Chile and South Africa were considered of interest for foreign investors. Other countries in the South American and Sub-Saharan Africa regions were benefiting from aid and technical assistance from European Union countries, the United States, and international institutions among others. ${ }^{40}$

Nowadays, the situation described above has changed. Investors from Europe, China, and the United States consider Sub-Saharan African and South America as regions attractive for foreign direct investment. The World Investment Report 2014 states that foreign direct investment rose in Africa by $4 \% 41$ whereas in Latin America after a few years of increase it has declined by $6 \%$ for the whole region although for some countries such as for instance Colombia it rose by $8 \% .42$

If one example may illustrate this is the change of focus from European countries such as the Netherlands towards Colombia on investment rather than on aid. ${ }^{43}$ Colombia is regarded as a partner for investment, and Dutch companies are currently involved in projects in Colombia providing services in areas such as infrastructure, water services, environmental protection, agribusiness and greenfield investments, etc. This is also true for investors all around the world since Colombia is currently regarded as a country attractive for investment and it is shown for instance in the World Investment Report 2014 that includes in the list of the top twenty host economies Brazil, Chile and Colombia. ${ }^{44}$

Other countries such as Peru and Ecuador are also being regarded as potential market for foreign investors in the same direction as Colombia. However, this is not true for all countries in South America, since for instance Bolivia is still depending on the exploitation of natural resources. In

\section{Notes}

39 A paper containing the main findings of this research for the selected countries will be available soon. Website of the DeSTaT Project: http://www.jus.uio.no/ior/english/research /projects/global-tax-tranparency/.

40 Governmental Institutions providing aid and technical assistance are for instance the German Tax Cooperation GIZ, the United Kingdom Department for International Development among others. International Institutions are for instance the International Finance Cooperation of the World Bank and the International Monetary Fund among others.

412014 World Investment Report. United Nations Conference on Trade and Development UNCTAD.: Investing in the Sustainable Development Goals SDGs: An Action Plan at XIX. Available at http://unctad.org/en/PublicationsLibrary/wir2014_en.pdf (Accessed February 2015).

42 Ibid., at 20

43 These three countries are regarded as transitional countries, according to the Brochure of June 2012 published by the Dutch Ministries of Foreign Affairs and of Economic Affairs. Brochure: 'Colombia, Vietnam and South Africa. In transition from Aid to Investment,' The Transition Facility stimulates Dutch entrepreneurs and those from Colombia, Vietnam and South Africa to improve the investment climate alongside centres of expertise and government bodies. See information available at http://english.rvo .nl/subsidies-programmes/transition-facility-tf.

442014 World Investment Report at XV. (Accessed February 2015). 
contrast to the dependence on aid in Sub-Saharan African Countries, aid to countries in South America has stagnated due to the development of their market economies (Brazil and Colombia) or their aid programmes are phasing out due to the graduation of these countries to lower-middle income status (e.g., Bolivia). ${ }^{45}$

Several African countries are regarded as conflict countries with political instability and therefore limited in their opportunities for attracting investment. These countries benefit from aid and/or technical assistance. ${ }^{46}$ However, other countries in the Sub-Saharan African region are considered as potential market for foreign companies either in respect of the extractive industry ${ }^{47}$ or investment on telecom, breweries, agriculture, etc. ${ }^{48}$ These countries are for instance in accordance to the Investment Survey provided in the BEPS report: 'Implications on Low Income Countries': South Africa, Uganda, Kenya, Rwanda, Ethiopia, Tanzania, Mozambique, Burundi. ${ }^{49}$ Other investment survey also includes Zambia, Ghana, and Nigeria as new foreign direct investment hotspots emerging in Sub-Saharan Africa. ${ }^{50}$

What this all means is that the solutions to tackle tax base erosion and aggressive tax planning should take into account the country and its attractiveness for investment that may generate or not aggressive tax planning opportunities. For countries that are still depending on aid or on the extractive industry and that have a very limited or no tax treaty network, the solutions should be first to provide more transparency of the payments made to these governments in respect of aid, or in respect of the extractive industry. Transparency may be obtained by means of disclosure of payments received by the government following for instance the model of the Extractive Industry Transparency Initiative. ${ }^{51}$ Other solutions are the change of concession sharing agreements for production sharing agreements, and the repeal of stability agreements for the extractive industry. When these countries are ready to start with the negotiation of tax treaties, then the countries will need make a cost/ benefit analysis of concluding a tax treaty, the use of the OECD or UN Tax Treaty Model, and to hire a qualified group of experts at the Ministry of Finance with knowledge of languages and with experience in international tax treaty negotiation.

Countries that are regarded as potential targets for investors and that have a tax treaty network may have a higher risk of aggressive tax planning -by means of for instance tax schemes to reduce the withholding tax- exists. Therefore, it is this author's opinion that for these countries specific measures should be introduced that prevent treaty shopping and other forms of tax treaty abuse that result in less withholding taxes being paid. The withholding taxes may be reduced by means of activities being carried out mainly from offshore jurisdictions, or countries with holding or conduit regimes, or countries with tax treaties that are lacking treaty abuse provisions beyond the beneficial ownership clause. One may think for South America, the use of Curacao ${ }^{52}$ and Spain. ${ }^{53}$ For

\section{Notes}

45 See 2012 DAC Report on Aid Predictability: Survey on Donors' Forward Spending Plans 2012-2015 and efforts since HLF-4 at 6 Available at http://www.oecd.org/dac/aid-architecture/2012_DAC_Report_on_Aid_Predictability.pdf (Accessed February 2015).

46 The Official Development Assistance to developing countries in 2013 rose by 6.1 per cent in real terms compared to 2012, after two years of falling volumes. See 2014 UNDP: The Millennium Development Goals Report: Goal 8 at 48. Available at: http://www.undp.org/content/dam/undp/library/MDG/english/UNDP\%20MDG\%20Repor $\% 202014 \% 20$ EN\%20Final.pdf (Accessed February 2015).

See also Ch. 5 Official Development Assistance of the United Nations Development Programme (UNDP) Report: Towards Human Resilience: Sustaining MDG Progress in an Age of Economic Uncertainty. 13 Oct. 2011. Available at http://www.undp.org/content/dam/undp/library/Poverty\%20Reduction/Towards_SustainingMDG_Web1005. pdf (Accessed February 2015).

47 According to the IMF Regional Economic Outlook: Sub-Saharan Africa: Keeping the Pace. October 2013, the group of resource exporters includes Angola, Botswana Burkina Faso, Cameroon, the Central African Republic, Chad, the Democratic Republic of the Congo, Republic of Congo, Equatorial Guinea, Gabon, Ghana, Guinea, Mali, Namibia, Niger, Nigeria, Sierra Leone, South Africa, Tanzania, Zambia, and Zimbabwe. See IMF Regional Economic Outlook at 7 available at https://www.imf.org/external/ pubs/ft/reo/2013/afr/eng/sreo1013.pdf (Accessed February 2015).

48 See for Sub-Saharan Africa the tables on investment and foreign direct investment in the See IMF Regional Economic Outlook: Sub-Saharan Africa: Keeping the Pace. October 2013 at 86 and 100. The IMF Regional Economic Outlook of Sub-Saharan Africa: Fostering Durable and Inclusive Growth and mainly in the issues regarding poverty rather than on aid and foreign direct investment.

49 Investment Motivation Survey presented in Part 1 of a Report to G20 Development Working Group on the Impact of BEPS in Low Income Countries, supra n. 6 at 21

50 See (Ernst \& Young) EY's Attractiveness Survey. Africa 2014: Executing growth at 8. Report available at: http://www.ey.com/Publication/vwLUAssets/EY-attractiveness-africa -2014/\$FILE/EY-attractiveness-africa-2014.pdf (Accessed February 2015).

51 The Extractive Industries Transparency Initiative (EITI) is now being used by 46 countries all around the world. Information available at http://eiti.org/ (Accessed February 2015).

52 Curacao has an offshore tax regime that will end in 2019. In order to replace that regime, a new Export Regime for companies engaged primarily in transactions with foreign clients has been introduced in 2014. Under the Export Regime, the profits of the qualifying companies will be subject to an effective tax rate of approximately $4 \%$. Information available at http://www.deloitte.com/assets/Dcom-NetherlandsAntillesAruba/Local\%20Content/Articles/3New\%20export\%20regime\% 20 CUR\%202014 pdf (Accessed February 2015).

53 In Colombia, for companies it is submitted that one of the structures identified until now by the Colombian tax authorities is the use of holding companies in Spain that are exempted of taxation in Spain (i.e., ETVEs). Spain has a tax treaty with Colombia where minimum requirements (only beneficial owner) exist in respect of substance for dividends. For the application of the treaty, in Colombia withholding tax on dividends paid by Colombia to these Spanish entities i.e. ETVES will be reduced to 0\% for substantial shareholding (i.e., 20\%) or 5\% in other cases. In Spain, the ETVES will not be taxed on these dividends. The result is then lower or no taxation. See Tax Planning with ETVES and tax evasion. Article Juan Esteban Sanín Gómez in the Portafolio of 25 Nov. 2011. See http://www.portafolio.co/opinion/blogs/juridica/planeacionfiscal-internacional-etves-y-las-clausulas-anti-elusion (Accessed February 2015). 
Sub-Saharan Africa, one example is the use of South Africa's preferential headquarter company regime to carry out investments throughout the whole region. ${ }^{54}$

Developing countries in South America and SubSaharan Africa have also other issues that need to be addressed and that are at this moment outside the scope of the BEPS. These issues are the use of tax incentives, ${ }^{55}$ lack of expertise in drafting complex provisions in the tax treaty or in their application by the tax administration, and/or the use of the OECD Model reducing the taxing right of these countries on management fees, technical services, royalties and in some cases dividends and interest. Among the issues that may derive from the complexity of tax treaty negotiations, one may think for instance in the limitation on benefits clause that may result in different approaches depending on whether on the other side of the negotiation table there is a developed country (such as the United States, Canada, Switzerland, Belgium or the Netherlands) or a developing country.

One of the features of countries in South America and Sub-Saharan Africa is that these countries as host countries may agree on bilateral investment treaties to protect the foreign investor. ${ }^{56}$ The use of these treaties is currently being revisited since investors may use these treaties to prevent going to local courts and instead to seek compensation in international tribunals. ${ }^{57}$ One of the consequences of the use of bilateral investment treaties is that developing countries may be bound by the provisions of these treaties. In these cases, it could be possible that the removal of the incentives may result in indirect expropriation for which compensation can be claimed following an investor-state dispute.
Furthermore, investors may use countries with an extensive bilateral investment treaty network only for purposes of treaty shopping i.e., investment made through a third country only for the purposes of having the treaty protection provided by the treaty concluded by such third country. Example could be the use of the investment treaty network of South Africa (forty-six signed from which only half have entered into force); Mozambique (twenty-four signed from which nineteen have entered into force); and Mauritius (forty-one signed and at least fourteen have been signed with African countries resulting in Mauritius being a potential attractive third country to carry out investments in Africa). ${ }^{58}$ Most of these treaties do not include provisions to ensure environmental protection, to protect health/moral/welfare, to address corporate social responsibility and/or to enhance sustainable development. ${ }^{59}$ These provisions may be important if the developing country wants the country of residence of the investor including the investor to commit to provisions that protect the environment, enhanced corporate tax behaviour by paying the right amount of tax and to ensure that the investment made in the country is sustainable. ${ }^{60}$

Another feature is that countries in South America and Sub-Saharan Africa agree on the use of stability clauses/ contracts that may result in tax base erosion and in the limitation of the government's power to levy taxes. These countries agree on stabilization clauses/contracts with investors (companies) in order to protect the investor from changes in the tax legislation. These clauses effectively guarantee that legislative changes will not be applicable to the taxpayer for the period of the contract/clause (i.e., five, ten or twenty years). Such stability clauses have previously

\section{Notes}

54 This Headquarter Company Regime is available since 2011 and it was created in order to promote South Africa as a holding company jurisdiction and to create the opportunity for South Africa to act as a gateway to Africa. Information available at http://www.kpmg.com/ZA/en/IssuesAndInsights/ArticlesPublications/Tax-and-LegalPublications/Pages/South-Africa-Headquarter-Company-Regime.aspx (Accessed February 2015).

55 This result in base erosion through wasteful tax incentives designed to attract investment. The report stated:

that in 2011, the OECD and other international organisations reported to the G20 DWG that tax incentives, including corporate income tax exemptions in free trade zones, continue to undermine revenue; where governance is poor, they may do little to attract investment — and when they do attract foreign direct investment (FDI), this may well be at the expense of domestic investment or FDI into some other country.

Part 1 of a Report to G20 Development Working Group on the Impact of BEPS in Low Income Countries, supra n. 6 at 21.

56 Bilateral Investment Treaties aim to protect the foreign investor in the host state from expropriation and discriminatory treatment by means of introducing national treatment, compensation for expropriation and dispute resolution clauses.

57 For instance in Colombia, the president has issued a Presidential Directive No. 4 of 11 Nov. 2014. In such Directive, the President addressed the dispute resolution clauses in contracts between the State and private parties (including foreign investors). He states that whether or not the dispute should be solved by international tribunals should be carefully analysed on a case-by-case basis and that in principle should be the Administrative Court in Colombia the one with the competence to decide on the disputes arising between the State and private parties.

58 According to the United Nations Commission on Trade and Development (UNCTAD), South Africa has the most bilateral investment treaties i.e. forty-six signed, of which only half have entered into force. All the other Sub-Saharan African countries have also signed five or more BITs, although only between one third and half have entered into force (with the exception of Mozambique, where UNCTAD reports that twenty of the twenty-four have entered into force). UNCTAD statistics, available at: http://www.unctad .org.

59 Example of these provisions may be found in the Model International Agreement on Investment for Sustainable Development. Available at http://www.iisd.org/pdf/2005/ investment_model_int_agreement.pdf.

60 These issues have been addressed by the United Nations Conference on Trade and Development (UNCTAD) and developing countries. See for instance the 2014 World Investment Report: Investing in Sustainable Development Goals: An Action Plan. Available at http://unctad.org/en/pages/PublicationWebflyer.aspx?publicationid=937 (Accessed February 2015) 
applied to the extractive industry (e.g., Ghana, Zambia and South Africa) and to specific economic sectors (e.g., Colombia until 2012,61 Peru and Chile ${ }^{62}$ ).

The lack of information on stability clauses for instance in Sub-Saharan Africa leads to less transparency and accountability on the part of investors and governments regarding the potential benefits of such clauses. ${ }^{63}$ In fact, the Tax Justice Network in Africa argues that these clauses prevent future governments from renegotiating contract provisions, possibly including limits to length of the contracts' and therefore reduce the governments' bargaining power in international negotiations. ${ }^{64}$ In Colombia, these stability contracts have been repealed as of 2013 and the contracts that were concluded in the past have been made publicly available, ${ }^{65}$ but it has not been the same situation in Peru and Chile.

\subsection{Tax Administration Capacity and Resources}

The use of Action 6 proposed measures such as limitation on benefits clause and a general anti-abuse clause to tackle treaty shopping should be revisited for countries in South America and South Africa depending on the capacity and resources of the tax administration. As rightly stated in the Public Discussion of Action 6 at the OECD Headquarters in January 2015, the proliferation of treaty abuse measures may result in administrative burden for the countries that are going to implement such measures. Furthermore, in some countries such as Colombia, not only the tax treaty abuse rules but also the domestic tax avoidance rules may apply. Therefore, the taxpayer will have to proof not only the compliance with the tax treaty but also with the requirements stated in the domestic anti-avoidance rules. ${ }^{66}$

The tax administration of countries in the Sub-Saharan Africa and South America regions are currently facing tax challenges due to the international rules that are in the process of implementation in these countries. Examples of these rules are the application of transfer pricing provisions, the application of tax provisions such as beneficial ownership to prevent tax treaty abuse, and the exchange of information among tax administrations. The BEPS and its Action Plan brings more challenges including the development of international standards to address the digital economy, hybrid mismatches, redefinition of the concept of permanent establishment, and introduction of complex tax treaty abuse provision such as limitation on benefits among others.

In order for the tax administration to cope with these challenges, tax administrations in South America and SubSaharan Africa need to increase the human capacity and to increase their technical knowledge. It is this author's opinion that the changes should also take place within the country itself and it does depend on political willingness to take upon these changes. Nowadays most of the countries in the South American and Sub-Saharan Africa regions have few personnel working at the tax administration and subject to: long working hours, with lower salaries, in charge of several tasks, and with specific performance requirements (e.g., amount of tax money to be collected), etc. This situation may result in overburden and stress of the personnel at the tax administration and it may increase the risk of corruption.

Therefore, it is recommended to include changes to the $\operatorname{tax}$ administration. Some of these changes can be for instance, increase the number of personnel at the tax administration, invest in their training and pay better salaries, introduce changes in the organization so that several divisions are being created with different tasks. One may think for instance of the following departments within the tax administration: tax rulings, exchange of information, taxation of multinationals, taxation of small and medium enterprises, taxation of informal economy, economic tax policy, tax treaties negotiations, etc.

\section{Notes}

61 By means of these contracts, foreign direct investment in specific sectors can obtain contractual protection on its investments from three years up to a maximum of twenty years. Investors should pay $1 \%$ premium based on the amount of investment (reduced to $0.5 \%$ in unproductive periods. These stability contracts have been repealed in the 2012 Colombian Tax Reform. The only Stability contracts that will be still valid are the sixty-seven stability Contracts that have been already negotiated and the Contracts that are in the process of being approved before the Law entered into force (1 Jan. 2013).

62 These Legal Stability Contracts (LSCs) have been also introduced in Chile and Peru but with different approach to Colombia. The UNCTAD review provides a comparison between the main features of Legal Stability Contracts in Colombia, Chile and Peru. Accordingly, 'the concept is based on similar schemes in Chile and Peru but Colombia's approach is markedly different. Colombia adopts a negative list approach. The government may agree to stabilize any regulation, unless expressly excluded by law. LSCs in Chile and Peru are confined to a predetermined list (with some variation by sector) of favourable matters and there is no negotiation either of the scope of the provisions, their drafting or the duration of the contract'. Investment Review Colombia. July 2006. United Nations Conference on Trade and Development (UNCTAD) at 23 and 24.

63 A. Shemberg, Stabilization Clauses and Human Rights: A Research Project Conducted for IFC and the United Nations Special Representative to the Secretary General on Business and Human Rights, 11 Mar. 2008. Available at http://www.ifc.org/ifcext/enviro.nsf/AttachmentsByTitle/p_StabilizationClausesandHumanRights/\$FILE/Stabilization+Paper.pdf (Accessed February 2015).

64 The Nairobi Declaration on Tax and Development made at the Pan-African Conference on Taxation and Development, 25-26 Mar. 2010; information on the Tax Justice Network is available at: www.taxjusticeafrica.net.

65 Information available at https://www.mincomercio.gov.co/minindustria/publicaciones.php? id=17145 (Accessed February 2015).

66 In Colombia, abuse for tax purposes is the use or implementation, by means of one operation or a set of operations of any entity, legal act or procedure that aims to change, disguise or modify artificially the tax consequences that will be generated for the taxpayer or related parties, shareholders, or real beneficiaries. Article 869-1 of the Colombian Tax Code states that there will be a presumption of abuse of law in case three of the following criteria are being met: (i) transaction is between related parties; (ii) transaction makes use of tax havens; (iii) transaction includes a special entities regime or an exempt tax entity; (iv) the price agreed differs more than $25 \%$ of the arm's length price; (v) the conditions agreed by the parties would have not been agreed by third parties in similar circumstances. In all cases of abuse, the burden of proof is for the taxpayer. I. Mosquera, Sweeping Tax Reforms Takes Effect, Tax Notes Int'l 433 (4 Feb. 2013). 
In addition to the challenges in the capacity and technical knowledge of the tax administration, it is also important to enhance the relationship between the tax administration and the taxpayers in South America and Sub-Saharan Africa. Individuals and companies should be able to trust the tax administration so that an enhanced relationship can be created. However, this trust needs to be justified and based on the actions of the tax administration and the taxpayer. This relationship can be a top down approach e.g., tax audits or filing income tax return, or a horizontal approach where an agreement can be signed by the tax administration and the taxpayer that results in horizontal monitoring. ${ }^{67}$

Tax authorities need to be able to exchange information and to provide tax assistance in the collection of taxes. For this purpose, the tax authorities within a region should develop initiatives that provide for tax cooperation. Example of these initiatives can be for instance, to organize joint meeting of tax administrations, exchange of best practices, training provided by the OECD,${ }^{68}$ the UN or by regional tax organizations such as the African Tax Administration Forum (ATAF) and the Inter-American Tax Centre (CIAT). This training should be taken place at the country's tax administration facilities and also based not only on other countries experiences but tailored to each country's needs. The training should not only focus on drafting of income tax rules and negotiation of bilateral tax treaties, but also on tax enforcement and collection including tax audits.

In addition, countries in these regions that are not members of regional tax organizations may also consider becoming members of the regional tax organizations African Tax Administration Forum (ATAF) for SubSaharan Africa and Inter-American Tax Centre (CIAT) for South America. It is also recommended for countries in the Sub-Saharan Region to consider the adoption of the ATAF Agreement Mutual Assistance in Tax Matters, ${ }^{69}$ and for countries in South America, the CIAT Model Agreement on Exchange of Information ${ }^{70}$

Furthermore, some countries such as Colombia and South Africa have signed the Multilateral Competent Authority Agreement to automatically exchange Financial Account Information based on Article 6 of the Convention on Mutual Administrative Assistance in Tax Matters on 29
October 2014..$^{71}$ The main consequence is the commitment of these countries to Automatic Exchange of Information. It is recommended for other countries in South America and Sub-Saharan Africa to sign this Convention in order to have a framework to exchange information and to benefit from the new transparent environment. Another step towards transparency should be for countries in South America and Sub-Saharan Africa to endorse the Common Reporting Standard and the Competent Authority Agreement for Automatic Exchange of Financial Account Information developed by the OECD. ${ }^{72}$

However, in order to participate effectively in these initiatives, the developing countries need to increase the financial, technical and administrative capacity to deal with exchange of information including the automatic exchange of financial account information. The aim should be to protect the confidentiality of the information exchanged and also to make effective use of the information exchanged. The improvement in the tax administrations should include the use of modern office space and furniture, computers, salaries and benefits including performance awards, travel funds, internal electronic databases which access can be monitored to prevent manipulation of data, manual to provide guidance to employees to work on exchange of information cases, and the allocation of specific tasks to the personnel in accordance to the type of tax or issue for which the information will be exchanged (e.g., transfer pricing, active income including permanent establishment issues, passive income including interest, royalties, management fees; taxpayer being a small or medium enterprise.

\subsection{Specific Features Regarding the Use (or Not) of Domestic Laws and Tax Treaty Rules to Tackle Aggressive Tax Planning}

Another question that needs to be addressed is whether the measures provided in Action 6 and 12 are only suggestions to the countries, and if so what will be the value of such rules to tackle effective profit shifting and base erosion taking into account the anti-abuse rules that have been introduced by developing countries?

\section{Notes}

67 In this regard, Gribnau argues that in the Netherlands due to horizontal supervision multinational corporations are moving from aggressive tax planning towards tax risk management and certainty in the Netherlands. See H. Gribnau, Soft Law and Taxation: The Case of the Netherlands, 1(3) Legisprudence (2 Jan. 2007).

68 The OECD has for instance developed the Tax Inspectors Without Borders to transfer audit knowledge and skills to tax administrations in developing countries. Website: http: //www.oecd.org/tax/taxinspectors.htm (Accessed February 2015).

Information available at: http://www.ataftax.net/en/exchange-of-information.html (Accessed February 2015).

Information available at http://www.ciat.org/index.php/en/products-and-services/publications/models.html (Accessed February 2015).

71 The competent authority agreement is a multilateral framework agreement, with the subsequent bilateral exchanges coming into effect between those signatories that file the subsequent notifications under s. 7 of the agreement. The agreement specifies the details of what information will be exchanged and when, as set out in the Standard for Automatic Exchange of Financial Information in Tax Matters. Information available at http://www.oecd.org/tax/exchange-of-tax-information/multilateral-competent-authority -agreement.htm (Accessed February 2015).

72 Common Reporting Standard available at the OECD Website http://www.oecd.org/ctp/exchange-of-tax-information/automaticexchange.htm (Accessed February 2015). 
Countries have until now tackled aggressive tax planning by means of enhancing administrative cooperation i.e., concluding agreements to exchange information and administrative assistance to ensure tax compliance. In addition, countries have introduced antiabuse rules in tax treaties and in national rules. Examples of these rules in tax treaties are the beneficial ownership, the limitation on benefits test, the main purpose test, the subject to tax clause amongst others. At national level, countries have introduced general anti-avoidance rules such as substance over form, business purpose, and abuse of law amongst others. ${ }^{73}$

It has to be kept in mind that these rules are present in bilateral tax treaties or in domestic laws, and that these rules may deviate among countries and among treaties. The OECD, the UN, and Regional Organizations should develop one or two anti-abuse rules in a multilateral instrument with specific exemptions and transitional rules. Until now, the OECD in the BEPS and mainly in the Action 6 Draft has provided for a limitation on benefits provision and a general anti-abuse clause. Since this Draft received critical comments and it is now in the process of being revisited, it could be relevant for the OECD to take into account the differences among antiabuse rules set up by countries, the difficulties by the tax administration to apply complex anti-abuse rules, the prevalence of domestic rules above treaty rules (treaty override in case the tax treaty has not allowed the use of such domestic rules) and the development of specific regional initiatives to help tax administrations in South America and Sub-Saharan African countries to tackle aggressive tax planning.

In the same direction, Action 12 should also take into account the differences among non-OECD countries and perhaps to find out one international instrument containing the disclosure rules for aggressive tax planning so that the taxpayer (whether small or large enterprise) does not have to incur in extra costs to meet the disclosure rules of each country. This international instrument for disclosure should also provide a general overview of the economic activities of a country in accordance to the different regions. For the design of such international instrument to provide disclosure, the OECD, the UN and the regional organizations may benefit from examples of reporting and transparency initiatives such as the Extractive Industry Transparency Initiative $^{74}$ and the
Country-by-Country Reporting. The approach to Country-by-Country Reporting recommended in this article is broader than the recommended in the BEPS Project in respect of Transfer Pricing (Action 13 BEPS Transfer Pricing Documentation and Country-by-Country Reporting). The approach that this article recommends is the disclosure of payments made to governments. The latter approach is at the time of writing being discussed at European Union level for extractive and forestry industries. $^{75}$

Finally, for multinationals it could be also possible to include requirements of disclosure of tax avoidance schemes in the public biding of these companies in projects carried out in South America and Sub-Saharan Africa. Since multinationals are currently operating in these countries by developing projects for infrastructure, water services, telecom industry, breweries, agriculture, etc., this measure of disclosure in the procurement rules could be an interesting way to reinforce transparency and also to tackle aggressive tax planning by multinationals. In case that the multinational fails to pay taxes, it will constitute a legitimate reason for the public contract to be terminated. This model may follow the current (2014) developments in EU Procurement that have resulted in the amendment of the EU Procurement Directives. ${ }^{76}$

\section{Conclusions AND ReCOMmendations}

The BEPS and its Action Plan have been developed by the OECD following the G20 mandate and it provides new international (multilateral) tax standards to be applicable to all countries including OECD and non-OECD countries. This article has assessed the feasibility of the BEPS and its Action Plan mainly Action 6 and 12 for countries in South America and the Sub-Saharan African Regions.

The main conclusion is that the feasibility of the BEPS and its Action Plan mainly Action 6 and 12 to tackle aggressive tax planning should be revisited. The main argument is that in South America and Sub-Saharan Africa, the solutions depend upon the country's economic development, tax administration capacity and resources, and the specific features of each tax system.

The starting point of the BEPS is that the tax systems are different all around the world, and due to the interaction of tax systems and to overlaps in the countries

\section{Notes}

3 For example, in Colombia the doctrines of simulation (before 2012) and abuse of law and substance over form (since 2012); in Uganda the substance over form doctrine; and in South Africa the business purpose doctrine.

Supra n. 51.

Information available at http://ec.europa.eu/internal_market/accounting/country-reporting/index_en.htm (Accessed February 2015).

This requirement for paying taxes to be participant in public bidding has been now introduced in the EU Procurement Directives that were adopted by the EU Council on $11 \mathrm{Feb} .2014$ and that should be transposed into domestic law of EU Countries by April 2016. See for instance Recital 100 and Art. 57(2) Directive 2014/24/EU of the European Parliament and of the Council of 26 Feb. 2014 on public procurement and repealing Directive 2004/18/E. The Directives that have been modified are Directives 2004/17/EC (procurement in the water, energy, transport and postal services sectors) and 2004/18/EC (public works, supply and service contracts), as well as the adoption of a directive on concession contracts. Information available at website EU on procurement at: http://ec.europa.eu/internal_market/publicprocurement/modernising_rules/reform _proposals/index_en.htm (Accessed February 2015). 
taxing rights, the result may be low taxation or no taxation at all. ${ }^{77}$ The BEPS Action Plan states:

new international standards must be designed to ensure the coherence of corporate income taxation at the international level. BEPS issues may arise directly from the existence of loopholes, as well as gaps, frictions or mismatches in the interaction of countries' domestic tax laws. ${ }^{78}$

In addition, the BEPS Action Plan states that:

there is a is a need to complement existing standards that are designed to prevent double taxation with instruments that prevent double non-taxation in areas previously not covered by international standards and that address cases of no or low taxation associated with practices that artificially segregate taxable income from the activities that generate it. ${ }^{79}$

What this all means is that the OECD has recognized in the BEPS and its Action Plan that the mismatches exists due to the differences in the tax systems. These mismatches may result in double taxation, but also in situations where no taxation or lower taxation occurs. The OECD aims with the Action Plan to develop new international standards to tackle these situations, but it is not yet clear the feasibility of the introduction of these standards in countries where the tax administration is still dealing with general tax auditing problems regarding transfer-pricing issues ${ }^{80}$ or with the introduction of tax incentives to attract investment. ${ }^{81}$

It is this author's opinion that the OECD should take into account in the report of the BEPS Action Plan for Low Income Countries whether the international standards proposed in the Action Plan should be the same for OECD and non-OECD countries. If not, what distinctions should be drawn in respect of countries in South America and the Sub-Saharan African region (mainly non-OECD countries)? It is this author's opinion that the OECDBEPS should take into account the commitment of developing countries to the OECD as well as their priorities for attracting investment, reducing aid dependency and developing (or not) a tax treaty and a bilateral investment and tax treaty network.

Some countries are currently in the process of becoming members of the OECD (i.e., Colombia), or are participating in an enhanced agreement (i.e., Brazil and South Africa). These countries can be more willing to participate and adopt the instruments provided by the BEPS Action Plan. Some issues may be conflicted such as for instance, for Brazil, the introduction of the changes in the BEPS Action Plan to the transfer pricing rules which may not be relevant for Brazil since this country does not follow the arm's length price ${ }^{82}$ of the OECD, or for instance, the use by Colombia of domestic anti-abuse rules in tax treaty situations. The application of the anti-abuse rules in Colombia may conflict with the tax treaty rules to prevent tax abuse provided in Action 6.83

Other countries are currently focusing on other nonBEPS issues. Among these issues are for instance tackling corruption, taxing natural resources, introducing tax holidays and basic transfer pricing rules, concluding stability contracts and/or bilateral investment treaties. This can be the case in a great number of the countries of the Sub-Saharan African region that are still in the process of developing their own tax systems, and to reduce their dependence on aid by means of attracting foreign direct investment. These countries are for instance Burkina Faso, Ethiopia, Mozambique, Rwanda, Tanzania, and Uganda. ${ }^{84}$ In South America, the situation may be also true for countries such as Bolivia and Paraguay that are still in the process of modernizing their own tax systems.

It should be kept in mind that non-OECD countries and mainly countries in South America and the SubSaharan African regions have other priorities (e.g., erosion

\section{Notes}

77 'The interaction of independent sets of rules enforced by sovereign countries creates frictions, including potential double taxation for corporations operating in several countries. It also creates gaps, in cases where corporate income is not taxed at all, either by the country of source or the country of residence, or is only taxed at nominal rates'. OECD (2013), Action Plan on Base Erosion and Profit Shifting, OECD Publishing, at 9, available at http://dx.doi.org/10.1787/9789264202719-en (Accessed February 2015).

78 Ibid., at 13

79 $\quad$ Ibid.

80 General transfer pricing issues could be for instance, the introduction of transfer pricing rules in the Tax Code, the rules to determine the arm's length method, the definition of comparables, transfer pricing compliance and analysis, and the use of advanced pricing arrangements among others. Complex issues could be for instance transfer-pricing rules for financial transactions, application of the interquartile range, adjustment to the median when the taxpayer's margins or prices fall out of the interquartile range, and considerations of the industry and/or life business cycles.

81 The issue of tax incentives has been identified as a problem for developing countries in the OECD report (first part) of the implications of the BEPS in Low Income Countries. The OECD addresses the concern of the International Monetary Fund in respect of the existence of tax incentives including tax holidays that also affect developing countries in addition to aggressive tax planning practices. Therefore, the OECD and the IMF recommend that these incentives should be revisited. Part 1 of a Report to G20 Development Working Group on the Impact of BEPS in Low Income Countries, supra n. 6, at 21.

82 Instead, Brazil uses fixed margins to calculate the price.

83 Colombia has made the anti-abuse rules introduced in the 2012 reform available not only for domestic but also for tax treaty situations which may result in tax treaty override in case that the double tax treaty does not allow for the use of domestic anti-abuse rules. It is submitted that treaty override brings more uncertainty to the taxpayers since in addition to the tax treaty anti-abuse rules, domestic rules (including tax administration rules and case law) regulating abuse of law or substance over form will be also decisive to determine whether a transaction is disregarded or not for tax purposes.

84 See IMF Regional Economic Outlook: Sub-Saharan Africa: Keeping the Pace. October 2013 at 44 and 45. Available at https://www.imf.org/external/pubs/ft/reo/2013/afr/eng /sreo1013.pdf (Accessed February 2015). 
of the tax base through tax incentives, reduction of withholding tax through treaty shopping, the use by the foreign investor of bilateral investment treaty's dispute resolution to bypass local courts or use by foreign investor of stability clauses to pay less taxes, etc.). These objectives should be addressed by the OECD when implementing the BEPS and by the International Conference when developing the multilateral instrument for developed and developing countries.

Therefore, it is submitted that the OECD and the International Conference developing the BEPS multilateral instrument should take into account the following:

(a) The economic development of the countries in South America and Sub-Saharan African is different among countries and among regions.

(b) Changes in the tax administration of countries in South America and Sub-Saharan African regions should aim at (i) increasing the human capacity, (ii) promoting integrity to prevent corruption, and (ii) increasing their technical knowledge. These objectives are to a great extent depending on the political willingness of these countries. Therefore, these countries will have to introduce changes such as to increase the number of personnel at the tax administration, to invest in their training, to pay better salaries, to tackle corruption, and to introduce changes in the organization so that several divisions are created with different tasks (e.g., ruling team, exchange of information, taxation of multinationals, taxation of small and medium enterprises, taxation of informal economy, economic tax policy, tax treaty negotiations, etc.)

(c) The relationship between the tax administration and the taxpayers should be enhanced based on trust that is justified on the actions of the tax administration and the taxpayer. This relationship can be a top down approach e.g., tax audits or filing income tax return, or a horizontal approach where an agreement can be signed by the tax administration and the taxpayer that results in horizontal monitoring. The result should be then a relationship based in mutual trust between the tax administration, and taxpayers.

(d) The OECD should take into account that the BEPS measures should be tailored to the countries and to the regions since one size does not fit all. Some countries are currently in the process of becoming members of the OECD or are participating in an enhanced agreement. These countries may be to a certain extent more willing to participate and to adopt the instruments provided by the Action Plan. Other countries are focusing on other issues than the issues addressed in the Action Plan. These countries are for instance focusing on developing their own tax systems, enhancing tax compliance at national level, modernizing their tax administrations and on reducing their dependence on aid.

(e) Tax systems are different around the world, and therefore, the challenge is for the OECD, UN, and Regional Organizations to develop one international instrument addressing the different priorities of countries including the different approaches and priorities of the non-OECD countries of South America and Sub-Saharan Africa.

(f) More specifically, in respect of Action 6, the OECD, the UN and Regional Organizations should develop a general anti-abuse clause in a multilateral instrument with specific scenarios that may be opt-in/ opt-out as proposed in the Action 15 of the BEPS and the introduction of an alternative provision to the limitation on benefits clause. For this purpose, the OECD and the UN should take into account the differences among anti-abuse rules set up by countries, the difficulties by the tax administration to apply complex anti-abuse rules, treaty override issues, and the development of specific regional initiatives to help tax administration in South America and Sub-Saharan African countries to tackle aggressive tax planning.

(g) For Action 12, the OECD, the UN and Regional Organizations should develop an instrument to provide disclosure of aggressive tax planning transactions. This instrument may be developed following for instance examples of reporting and transparency initiatives such as the Extractive Industry Transparency Initiative and the Country-by-Country reporting with a broader scope than the one presented in Action 13 of the BEPS taking into account the proposal of the EU for the extractive and fisheries industries.

(h) Finally, countries should consider including requirements of disclosure of tax avoidance schemes in the public bidding by multinational companies in infrastructure, service projects carried out in South America and Sub-Saharan Africa. 


\section{[A] Aim of the Journal}

This established international tax journal offers detailed coverage of direct tax, indirect tax, and social security from both legal and economic angles, and provides 12 issues a year of practical, up-to-date, high-level international tax information. Coverage includes all aspects of transnational tax issues. The journal includes authoritative, reliable content, written for tax attorneys, practitioners (litigation and transactional) in other areas where international tax issues are a concern, and academics.

\section{[B] Contact Details}

Manuscripts should be submitted to the General Editor, Fred de Hosson.

E-mail address: Fred.deHosson@bakermckenzie.com

\section{[C] Submission Guidelines}

[1] Manuscripts should be submitted electronically, in Word format, via e-mail.

[2] Submitted manuscripts are understood to be final versions. They must not have been published or submitted for publication elsewhere.

[3] Articles in the non-peer reviewed sections should preferably not exceed 10.000 words and articles in the peer-reviewed section should preferably not exceed 14.000 words.

[4] Only articles in English will be considered for publication. Manuscripts should be written in standard English, while using 'ize' and 'ization' instead of 'ise' and 'isation'. Preferred reference source is the Oxford English Dictionary. However, in case of quotations the original spelling should be maintained. In case the complete article is written by an American author, US spelling may also be used.

[5] The article should contain an abstract, a short summary of about 200 words. This abstract will also be added to the free search zone of the Kluwer Online database.

[6] A brief biographical note, including both the current affiliation as well as the e-mail address of the author(s), should be provided in the first footnote of the manuscript.

[7] An article title should be concise, with a maximum of 70 characters.

[8] Special attention should be paid to quotations, footnotes, and references. All citations and quotations must be verified before submission of the manuscript. The accuracy of the contribution is the responsibility of the author. The journal has adopted the Association of Legal Writing Directors (ALWD) legal citation style to ensure uniformity. Citations should not appear in the text but in the footnotes. Footnotes should be numbered consecutively, using the footnote function in Word so that if any footnotes are added or deleted the others are automatically renumbered.

[9] Tables should be self-explanatory and their content should not be repeated in the text. Do not tabulate unnecessarily. Tables should be numbered and should include concise titles.

[10] Heading levels should be clearly indicated.

For further information on style, see the House Style Guide on the website: www.wklawbusiness.com/ContactUs/

\section{[D] Peer Review}

[1] At specific request by the author, an article can be submitted for peer review.

[2] In this procedure, articles are evaluated on their academic merit by two (anonymous) highly esteemed tax law experts from the academic world. Only articles of outstanding academic quality will be published in the peer-reviewed section.

\section{[E] Regular Review Process}

[1] Before submission to the publisher, manuscripts will be reviewed by the General Editor and Editorial Board and may be returned to the author for revision.

[2] The editors reserve the right to make alterations as to style, punctuation, grammar etc.

[3] The author will receive PDF proofs of the article, and any corrections should be returned within the scheduled dates.

\section{[F] Copyright}

[1] Publication in the journal is subject to authors signing a 'Consent to Publish and Transfer of Copyright' form.

[2] The following rights remain reserved to the author: the right to make copies and distribute copies (including via e-mail) of the contribution for own personal use, including for own classroom teaching use and to research colleagues, for personal use by such colleagues, and the right to present the contribution at meetings or conferences and to distribute copies of the contribution to the delegates attending the meeting; the right to post the contribution on the author's personal or institutional web site or server, provided acknowledgement is given to the original source of publication; for the author's employer, if the contribution is a 'work for hire', made within the scope of the author's employment, the right to use all or part of the contribution for other intra-company use (e.g. training), including by posting the contribution on secure, internal corporate intranets; and the right to use the contribution for his/her further career by including the contribution in other publications such as a dissertation and/or a collection of articles provided acknowledgement is given to the original source of publication.

[3] The author shall receive for the rights granted a fee of EUR 31,66 per page (in final layout), a free copy of the issue of the journal in which the article is published, plus a PDF file of his/her article. 